\title{
Molecular Characterization of Hypothalamo- Pituitary-Thyroid Genes in Pig (Sus Scrofa)
}

\author{
Ningying $\mathrm{Xu}$ and Xiaoling Jiang \\ Zhejiang University, \\ China
}

\section{Introduction}

Almost all the body functions of vertebrate animals including swine are regulated by the nervous system and endocrine system. Especially the hormones released from the endocrine system have effective biological amplifying effects. Minor changes in the hormone level could cause huge alternations in physiology.

Hypothalamus, extensively connected with other brain regions, is the vital bridge between nervous system and endocrine system. It exerts its regulating function on endocrine system mainly via the pituitary, which is the central endocrine organ in vertebrate animals. Except the growth hormone, most of the hormones secreted by pituitary have their specific target organs. For example, thyrotropin target thyroid. The hypothalamus, pituitary and target organs are always described together as "axis", e.g. hypothalamo-pituitary-gonadal axis, hypothalamo-pituitary-adrenal gland axis, and hypothalamo-pituitary-thyroid (HPT) axis.

\section{The axis of hypothalamo-pituitary-thyroid}

Hypothalamus synthesizes and secrets thyrotropin-releasing-hormone (TRH) to send regulating information to pituitary (see Figure 1). TRH binds to the thyrotropin-releasinghormone receptors (TRHR) on the thyrotroph cells of pituitary to activate the intracellular signal pathways and induce the secretion and synthesis of thyrotropin (TSH). Circulating TSH in blood then binds to the thyrotropin receptors (TSHR) on the follicular cells of thyroid to activate the synthesis and secretion of thyroid hormone (TH).

TH secreted by thyroid is important to growth, development, and protein, fat, and carbohydrate metabolisms (Porterfield and White, 2007). It acts on almost all the organs and tissues. Each individual has a unique thyroid function set-point, and this set-point was suggested to be genetically determined (Hansen et al., 2004). Genetic variations of the hormones of HPT axis and their respective receptors could be the excellent candidates as the causing of related phenotype variations.

\subsection{Thyrotropin releasing hormone gene (TRH)}

Thyrotropin releasing hormone, produced in the paraventricular nucleus of the hypothalamus, is fully conserved in all species from human to bony fish that have been 
investigated so far (Harder, 2001). It is the tripeptide pyro-Glu-His-Pro- $\mathrm{NH}_{2}$ derived from the preprohormone gene $T R H$, which also produces other non-TRH active peptides e.g. ppTRH $_{160-169}\left(\mathrm{pST}_{10}\right)$ and $\mathrm{ppTRH}_{178-199}\left(\mathrm{pFE}_{22}\right)$.

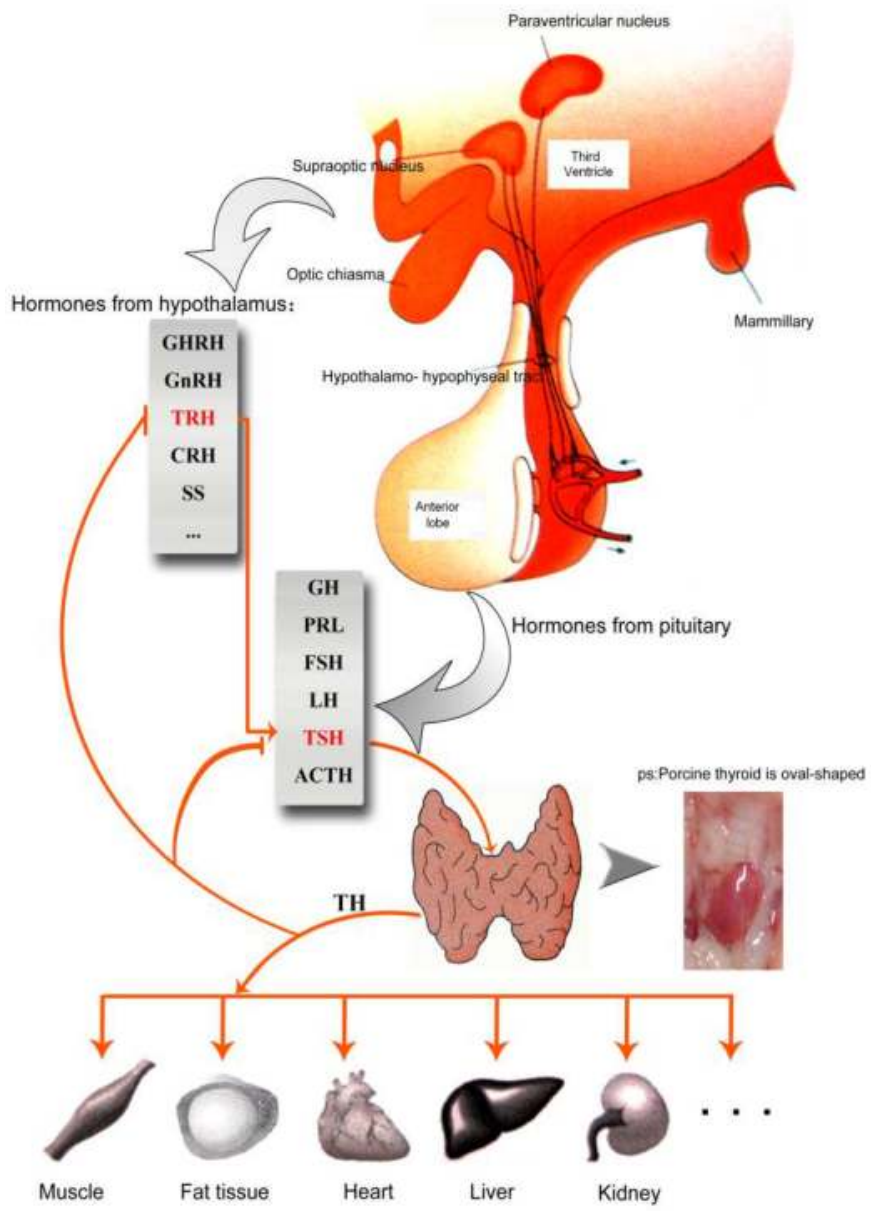

Fig. 1. Schematic map of hypothalamo-pituitary-thyroid axis regulatory network, according to Porterfield and White (2007).

No experiments on the porcine TRH gene have been done previously. However genomic information of this gene has became available as a result of the porcine whole genome sequencing, and comprehensive sequence analysis on it with bioinformatics method has been done (Wallis, 2010). Porcine TRH gene was found to be 3, 136 bp with 3 exons and two introns. A conserved signal peptide of 24 amino acids was predicted to be present, and there existed six copies of TRH sequences in the preprohormone peptide. 


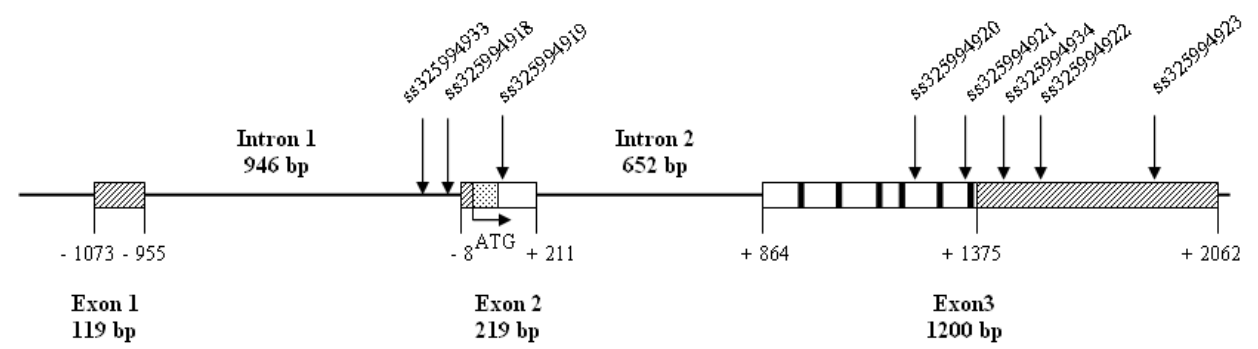

Fig. 2. The schematic map of the porcine TRH gene. Boxes represented the exons (according to Wallis), of which the regions filled with diagonal lines were un-translated regions (UTR), the region filled with dots represented the signal peptide, and the regions full filled with black color represented the six copies of TRH precursor peptides.

\subsection{Thyrotropin Releasing Hormone Receptor gene (TRHR)}

TRH initiates its effects by interacting with its receptor TRHR in the anterior pituitary. TRHR is a seven transmembrane spanning receptor and belongs to the G protein-coupled receptor superfamily. Actually, to date in total of three TRH receptors have been reported, each encoded by their specific genes. The first subtype of TRHR found in 1990 have been described in many species, e.g. mouse, rat, human, cow, chicken, frog and fish (Sun et al., 2003). However, the second subtype of TRHR identified in 1998 has only been reported in rodents, frog and fish. Further information of human genome sequence does not support the existence of the second TRHR subtype (Pfleger et al., 2004). The third TRHR subtype has only been reported in frog and fish (Mekuhi et al., 2010) so far. Figure 3 shows the evolution tree of the TRHR proteins.

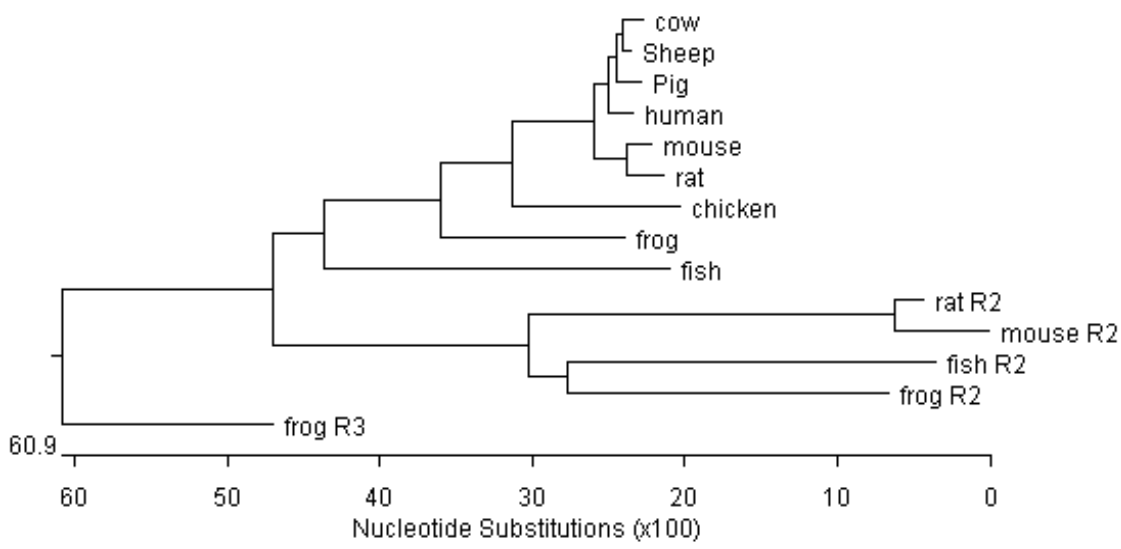

Fig. 3. Polygenetic tree of TRHR proteins, aligned with method Clustal W. The branch of fish used the TRHR sequence of Catostomus commerson.

Porcine TRHR gene (the first subtype) has been cloned and characterized recently (Jiang et al., 2011). It contains an open reading frame encoding 398 amino acids and shares $96.2 \%$ 
amino acid identity to human TRHR. An intron disrupts the open reading frame in the sequence encoding the putative third intracellular loop which is between the fifth and sixth transmembrane domain. Besides, alternative spliced transcript variants and multiple transcription start sites have been observed in porcine TRHR gene (Jiang, 2011). The biological functions of these variants remain investigations.

\subsection{Thyrotropin alpha subunit gene (CGA)}

Thyrotropin is a member of the glycoprotein hormone family which consisting thyrotrophin, follicle-stimulating hormone and luteinizing hormone in anterior pituitary, and chorionic gonadotrophin in the placenta. Each of these hormones is a heterodimer composed of a common a subunit and a hormone specific $\beta$ subunit. The common a subunit is encoded by the CGA gene, while the TSH specific $\beta$ subunit is encoded by the TSHB gene.

Porcine CGA gene is $14 \mathrm{~kb}$ in length and consists of four exons and three introns (Kato et al., 1991). The coding region starts from the exon 2 , and the premature peptide contains a signal peptide of 24 amino acids. Two intragenic microsatellites were found in intron 1 and intron 2. The microsatellite located in the intron 1 has been named as PGHAS or ALPHA and widely used in genetic studies as genetic marker.

\subsection{Thyrotropin beta subunit gene (TSHB)}

The porcine TSHB gene has at least two exons and one intron, and is $939 \mathrm{bp}$ in length. Its product consists of a signal peptide of 24 amino acid residues, a mature beta subunit protein of 112 residues and an additional extension of six amino acid residues at the carboxyl terminus (Hirai et al., 1989). The TSH beta subunit noncovalently links to the alpha subunit by wrapping with its "seat belt" structure around the alpha subunit's long loop aL2.

TSH $\beta$ subunit is responsible for the hormone specificity, and its translation rate directly determines the secretion and synthesis rates of the hormone TSH. Additionally, it has been reported that mature Chinese meishan pigs had 3 fold greater expressions of TSHB gene and greater plasma TSH concentrations than mature Western white composite pigs (Li et al., 1996).

\subsection{Thyrotropin receptor gene (TSHR)}

The receptor of the thyrotorpin,TSHR, belongs to the glycoprotein hormone receptor (GPHR) family which is a subset of the G-protein coupled receptor (GPCR) superfamily. It contains a seven-transmembrane domain and a large ectodomain composed of many leucine-rich repeats forming TSH-binding surface (Farid \& Szkudlinski, 2004).

The mRNA sequence of the porcine TSHR gene has been cloned in 2003 (Igarashi \& Nagata, 2003) and characterized to containing an open reading frame coding 764 amino acids. However, as the genomic sequence of porcine TSHR gene is still unavailable so far, the genomic structure of the gene is not clear. Of human, the TSHR gene was found to be $190 \mathrm{~kb}$ in length, and contains ten exons and nine introns, of which all the first nine exons encodes the large extodomain while the last exon is in charge of the seven transmembrane domains and the intracellular tail. 


\section{The gene mapping and expression analysis of these genes}

Quantitative trait loci (QTLs) are regions of the chromosome that are found to be associated with particular phenotypic traits by statistical analysis. Thus far, the pig QTL database (Pig QTLdb) has collected 6,344 QTLs from 281 publications in the past more than ten years. Any genes in these regions might be the positional candidate genes underlying the respective traits. Mapping the genes of HPT axis would help us to evaluate the potential genetic effects of the variations of these genes.

\subsection{The electrical mapping}

In April 2009, the International Swine Genome Sequencing Consortium has completed and released a $4 \times$ sequence depth draft (Sscrofa9) by a minimal tile path BAC by BAC approach. This assembly can be conveniently accessed by the web-based query on the Ensemble (http://www.ensembl.org/Sus_scrofa/Info/Index). Though a more recent assembly Sscrofa 10, a mixed BAC and WGS-based assembly of the porcine genome, has been released in April 2011, assemble errors in it remain to be resolved. Furthermore, the Pig QTLdb offered GBrowse map view of QTLs (http://www.animalgenome.org/cgi-bin/gbrowse/pig/) based on the Sscrofa 9. Thus, with the chromosome position of the candidate gene obtained by querying the Ensemble, one can easily get the information of the QTLs which were mapped onto the same genomic region (Figure 4).

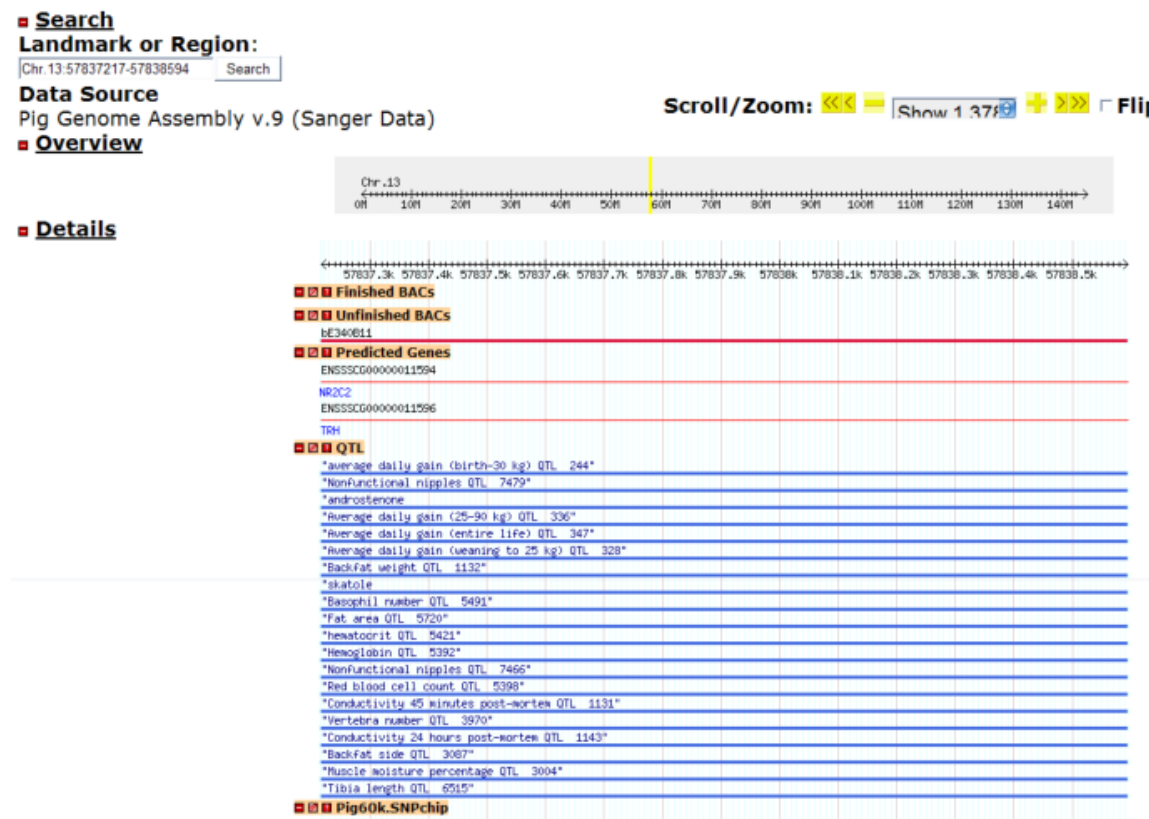

Fig. 4. Query result of pig QTLdb Gbrowse map view, using TRH as an example.

Porcine TRH gene is located between $57,837,217$ and $57,838,594$ on chromosome 13 . Based on the pig QTLdb, there are 20 QTLs including average daily gain (ADG), backfat weight, meat 
quality traits and blood parameters have been reported in this region. Porcine CGA gene is mapped between 58,190,063 and 58,192,283 on chromosome 1, and 21 QTLs have been mapped to the corresponding region, most of which are fat related traits. The position of TSHB gene on porcine chromosome 4 is from 109,815,329 to 109,816,276. 49 QTLs including ADG, backfat thickness (BFT) and meat quality related traits have been mapped to this position. Unfortunately, TRHR and TSHR genes had not yet been annotated in Sscrofa 9 in the year 2009 .

\subsection{The RH mapping}

Radiation hybrid (RH) mapping is a kind of somatic cell genetics tool for mapping candidate genes into a framework of microsatellites/sequence-tagged sites. First, RH panels are constructed by using a lethal dose of X-rays to fragment the chromosomes of the donor cell and the chromosome fragments with known genetic markers are retained randomly in the host cells. The frequency of breakage between pairs of markers in a panel of RH clones can be used to calculate the relative physical distances of the genetic markers or genes. Several porcine RH panels have been produced, among which the whole-genome highresolution IMpRH panel constructed by Yerle et al. (1998) is the most frequently used one.

The porcine TRHR gene was localized to the microsatellite SW969 on chromosome 4 by RH mapping using the IMpRH panel (Jiang et al., 2011). 44 Quantitative trait loci affecting BFT, daily gain, and carcass and meat quality traits have been mapped to the same region. TSHR gene has been mapped between microsatellites SW1083 and SW581 on porcine chromosome 7 (Sato et al., 2006), and 50 QTLs including BFT, ADG, carcass length and muscle related traits have been mapped to the same position.

\subsection{Expression analysis}

TRH is present not only in the hypothalamus but also in many other brain loci as a neuromodulator / neurotransmitter. Besides, expression of TRH gene is found in gastrointestinal tract, pancreas, reproductive tissues, heart, spleen, adrenals and thymus. Its receptor, TRHR is also found in gastrointestinal tract, pancreas, testis and adrenals. Paracrine effects of TRH on gastrointestinal tract and pancreas have been suggested. Furthermore, TSHR is widely expressed in many organs and tissues such as pituitary, heart, skeletal muscle and adipose. Species-specific expression of HPT genes in certain tissues might exist. For example, TRHR was detected in medaka spleen (Mekuchi et al., 2010) but undetectable in bovine spleen (Takata et al., 1998), and TSHB has been reported in the liver and reproductive organs of red drum (Cohn et al., 2010) but undetectable in the same organs of ducks (Hsieh et al., 2007).

Tissue distribution of HPT genes in pigs have been investigated by using real-time quantitative RT-PCR with RNA samples from 15 different organs/tissues including brain, hypot4halamus, pituitary, thyroid, lung, kidney, gastrointestinal tract, muscle and fat tissue (Jiang 2011). Highest expression level of TRH was found in the brain, and considerable level of TRH also expressed in testis, spleen, fat tissue, small intestine and pancreas in addition to hypothalamus. Porcine TRHR mRNA was detected in almost all the investigated organs/tissues except the spleen, with high expression levels in the brain, hypothalamus, 
pituitary, testis and fat tissue. The two subunit genes of hormone TSH showed different tissue distribution patterns. While CGA was detectable in almost all the tissues, TSHB was mainly existed in the pituitary and undetectable or in extremely low level in the other tissues except in the fat tissue and stomach. Expression of porcine TSHR existed in all the fifteen organs/tissues, with highest expression level in the thyroid, then the testis and spleen.

\subsection{The polymorphisms of these genes}

Polymorphism in human TRH gene has been reported to be associated with blood pressure variations and hypertension (Kokubo et al., 2006). By re-sequencing the whole coding region of porcine TRH gene, eight sequence variations were identified (Jiang 2011). Among these polymorphisms, only ss325994920 (Figure 2) is a missense mutation which would bring a Val to Met amino acid mutation into pFE22 and pSE14 peptides.

Mutations in the TRHR could result in central hypothyroidism which causes growth retardation, pudginess and sluggishness (Collu et a., 1997). Further TRHR polymorphism has been identified responsible for human lean body mass variations in a genome-wide association study (Liu et al., 2009). Re-sequencing the coding sequences and flanking regions of porcine TRHR gene identified seven polymorphic loci (Figure 5a). Two of them locate in the intron 1 which has been proven to encompass important regulatory elements.

Mice with CGA gene knockout were viable, but exhibited severe growth insufficiency and infertility (Kendall et al., 1995). While no inactivating mutations of CGA gene has been detected in humans and mice, cases of nonsense mutations of TSHB gene have been continuously reported in humans which cause growth retardation and fat metabolism disorders (McDermott et al., 2002; Baquedano et al., 2010). 14 new polymorphic loci of porcine CGA gene (Figure $5 b$ ) and 5 polymorphisms of TSHB gene (Figure $5 c$ ) were identified and confirmed by re-sequencing (Jiang et al., 2011b). Four of the CGA polymorphisms locate in the promoter region. The single nucleotide polymorphism ss181129018 of TSHB gene locates on the first coding exon and brings amino acid change to the signal peptide of TSH $\beta$ subunit.

TSHR is sensitive to point mutations and most of the reported human mutations existed in the last exon 10 (Davis et al., 2006). Re-sequencing the last exon of porcine TSHR gene detected three polymorphisms in the exon (Figure $5 \mathrm{~d}$ ), but all were synonymous mutations.

\section{The association study with economic traits in the crossbred of Jinhua and Pietrain}

A crossbred was established by mating the Chinese Jinhua pigs (Central China swine type) with European Pietrain pigs, and obvious segregation of growth, carcass and meat quality characters were observed in this population. Association study of the five HPT key genes' polymorphisms with the economic important traits in the crossbred of Jinhua and Pietrain were carried out by analyzing fourteen polymorphic loci with thirty traits of 463 individuals (Jiang 2011). Both PCR-RFLP and tetra-primer ARMS PCR procedure were utilized for genotyping, and haplotypes were considered as genetic effects. 
a) Porcine TRHR polymorphisms

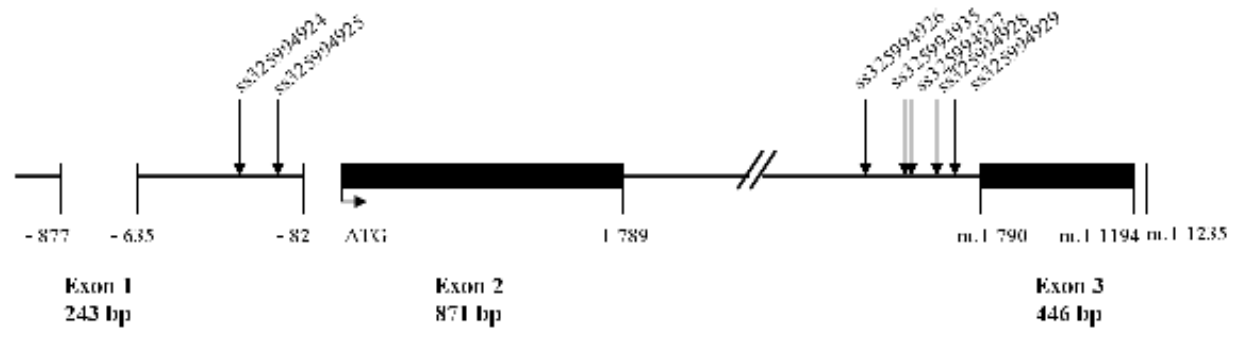

b) Porcine CGA polymorphisms

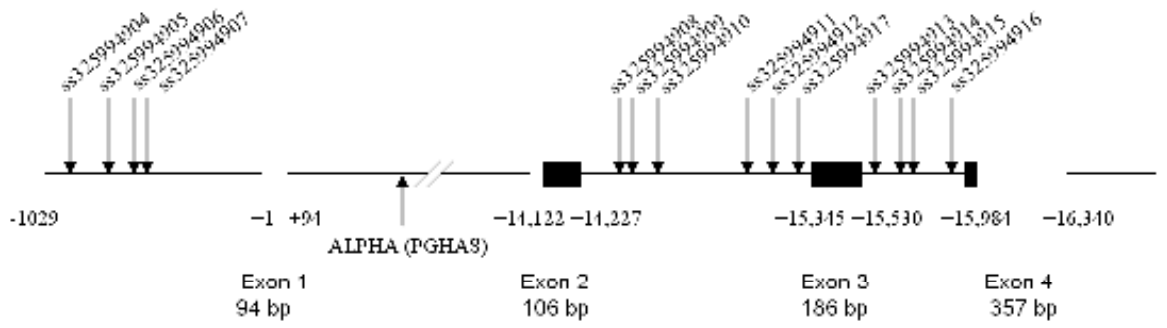

c) Porcine TSHB polymorphisms

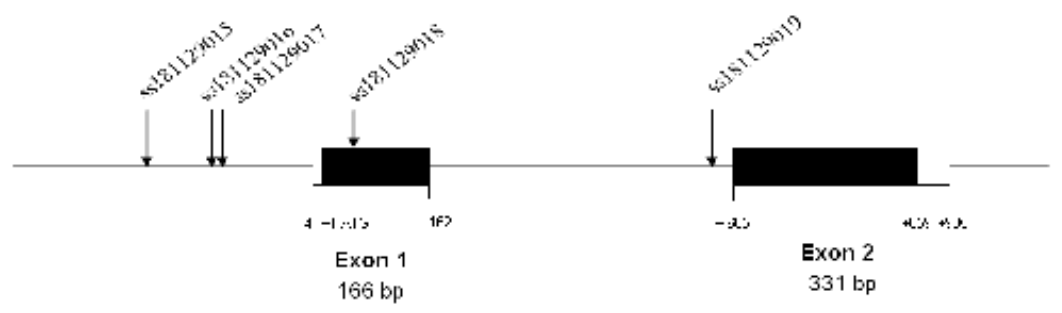

d) Porcine TSHR polymorphisms

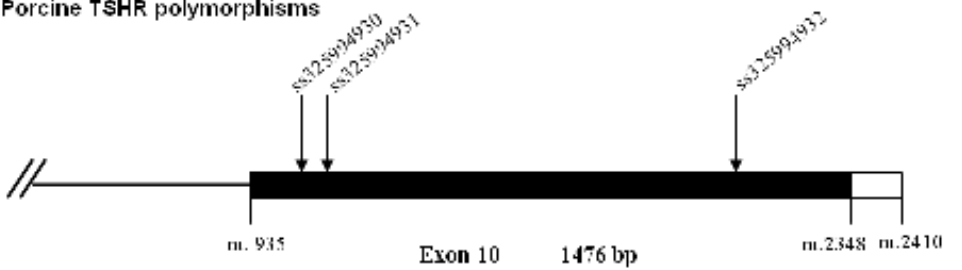

Fig. 5. Genetic Polymorphisms of porcine HPT axis

\subsection{Thyrotropin releasing hormone gene $(T R H)$}

Polymophisms of porcine TRH gene were divided into two linkage disequilibrium (LD) blocks. One of the LD block contained locus ss325994933 which was significantly $(\mathrm{P}<0.05)$ associated with daily weight gain. Homozygous individuals with the insertion allele showed higher daily weight gain than the ones with the deletion allele. TRH could be considered functional and positional candidate gene of the ADG QTL reported by de Koning et al. (de Koning et al., 2001). However, further investigation on the allele frequencies in different purebreds showed that the insertion allele mainly existed in the 
Chinese breeds, while the Western pig breeds those normally grow faster than the Chinese breeds were almost fixed with the deletion allele. Another LD block consisted of the other TRH polymorphisms investigated. No significant associations of this LD block with the economical traits were observed.

\subsection{Thyrotropin releasing hormone receptor gene (TRHR)}

All the four TRHR polymorphisms studied existed in one LD block. Significant associations of porcine TRHR gene with head weight, carcass length, and electric conductivity, $\mathrm{pH}$ value, water holding capacity, intramuscular water and fat content of loin muscle were observed. QTLs of carcass length (Wimmers et al., 2002; Murani et al., 2006) and intramuscular fat content (de Koning et al., 1999) have been reported previously. Individuals with the haplotypes originating from the Pietrain had smaller head weight, longer carcass length and lower conductivity of loin muscle. However, no significant difference among the haplotypes was observed after bonferroni corrections.

\subsection{Thyrotropin alpha subunit gene (CGA)}

As the existence of microsatellites in the porcine CGA gene, QTL mapping results around the CGA gene from different studies were instable. In the crossbred of Jinhua and Pietrain, haplotypes of CGA was only associated with intramuscular water content. But if further dissecting by dividing the gene with the microsatellites, the promoter region of this gene showed significant associations with growth and backfat thickness traits.

\subsection{Thyrotropin beta subunit gene (TSHB)}

Haplotypes of porcine TSHB gene were significantly associated daily weight gain between 90 to 120 days, ham muscle weight, and extremely significantly $(\mathrm{P}<0.01)$ associated with carcass weight, carcass length and average backfat thickness. Corresponding QTLs have also been reported in this chromosome region (Grindflek et al., 2001; Knott et al., 2002; Malek et al., 2001; Nagamine et al., 2003; van Wijk et al., 2007; Walling et al., 2000). The homozygous individuals with haplotype originating from Jinhua pig had significantly lower daily weight gain and thicker average BFT than the homozygous individuals with the haplotype originating from Pietrain, which were in accordance with the observations in the two purebreds. Further verification in a Duroc population confirmed the association of TSHB gene with the average BFT trait and showed that the allele A of ss181129015 which was popular in Western breeds was associated with lower average BFT. Porcine TSHB gene, especially the locus ss181129015 is worthwhile for further study and to be developed as genetic marker for the BFT trait.

\subsection{Thyrotropin receptor gene (TSHR)}

Individuals with allele A of TSHR ss325994932 showed higher daily gain between 120 to 180 days old and lower muscular pH value than the ones with allele $\mathrm{G}$ in the crossbred of Jinhua and Pietrain. Several QTLs on ADG around the TSHR gene have been reported previously (Edwards et al., 2008; Nagamine et al., 2003). Though individuals with allele A showed better performance in growth and meat quality in the crossbred, investigation on the allele frequencies in different purebreds showed that the allele A appeared in fairly low 
frequencies in all the purebreds studied. Verification in Landrace population confirmed the association of TSHR with ADG, but allele A was associated with slower growth rate in this breed. Possible explanations were interactions of alleles of TSHR with other genes' might exist, or recombination might have occurred between the causative polymorphism and ss325994932 in some breeds.

\section{Acknowledgment}

This work was supported by National Natural Science Foundation of China (NO. 30972078) and Main Research Projects of Zhejiang Province (NO.2006C004-2).

\section{References}

Baquedano MS, Ciaccio M, Dujovne N, Herzovich V, Longueira Y, Warman DM, et al. Two novel mutations of the TSH-beta subunit gene underlying congenital central hypothyroidism undetectable in neonatal TSH screening. J Clin Endocrinol Metab 2010; 95: E98-103.

Cohn WB, Jones RA, Valverde RA, Leiner KA, MacKenzie DS. Molecular cloning and regulation of mRNA expression of the thyrotropin beta and glycoprotein hormone alpha subunits in red drum, Sciaenops ocellatus. Fish Physiol Biochem 2010; 36: 1277-90.

Collu R, Tang J, Castagne J, Lagace G, Masson N, Huot C, et al. A novel mechanism for isolated central hypothyroidism: inactivating mutations in the thyrotropinreleasing hormone receptor gene. J Clin Endocrinol Metab 1997; 82: 1561-5.

Davies TF, Ando T, Lin RY, Tomer Y, Latif R. Thyrotropin receptor-associated diseases: from adenomata to Graves disease. J Clin Invest 2005; 115: 1972-83.

de Koning DJ, Janss LL, Rattink AP, van Oers PA, de Vries BJ, Groenen MA, et al. Detection of quantitative trait loci for backfat thickness and intramuscular fat content in pigs (Sus scrofa). Genetics 1999; 152: 1679-90.

de Koning DJ, Rattink AP, Harlizius B, Groenen M, Brascamp EW, van Arendonk J. Detection and characterization of quantitative trait loci for growth and reproduction traits in pigs. Livestock Production Science 2001; 72: 185-198.

Edwards DB, Ernst CW, Tempelman RJ, Rosa GJ, Raney NE, Hoge MD, et al. Quantitative trait loci mapping in an F2 Duroc $x$ Pietrain resource population: I. Growth traits. J Anim Sci 2008; 86: 241-53.

Farid NR, Szkudlinski MW. Minireview: structural and functional evolution of the thyrotropin receptor. Endocrinology 2004; 145: 4048-57.

Grindflek E, Szyda J, Liu ZT, Lien S. Detection of quantitative trait loci for meat quality in a commercial slaughter pig cross. Mammalian Genome 2001; 12: 299-304.

Hirai T, Takikawa H, Kato Y. Molecular cloning of cDNAs for precursors of porcine pituitary glycoprotein hormone common alpha-subunit and of thyroid stimulating hormone beta-subunit. Mol Cell Endocrinol 1989; 63: 209-17.

Hansen PS, Brix TH, Sørensen TIA, Kyvik KO and Hegedüs L. Major genetic influence on the regulation of the Pituitary-thyroid axis: a study of healty Danish twins. J Clin Endocrinol Metab 2004; 89: 1181-1187.

Harder S, Dammann O, Buck F, Zwiers H, Lederis K, Richter D, et al. Cloning of two thyrotropin-releasing hormone receptor subtypes from a lower vertebrate 
(Catostomus commersoni): functional expression, gene structure, and evolution. Gen Comp Endocrinol 2001; 124: 236-45.

Hsieh YL, Chowdhury I, Chien JT, Chatterjee A, Yu JY. Molecular cloning and sequence analysis of the cDNA encoding thyroid-stimulating hormone beta-subunit of common duck and mule duck pituitaries: in vitro regulation of steady-state TSHbeta mRNA level. Comp Biochem Physiol B Biochem Mol Biol 2007; 146: 307-17.

Igarashi M, Nagata A. Molecular cloning, sequencing and functional expression of porcine thyrotropin (TSH) receptor cDNA1). Clin Chem Lab Med 2003; 41: 796-803.

Jiang XL. Study on five key genes of porcine hypothalamo-pituitary-thyroid axis. Dissertation of Zhejiang University, 2011.

Jiang XL, Cai ZW, Zhao XF, Zhang LF, Chen Z, Wang Y, Guo XL, Xu NY. Mapping, cDNA cloning and tissue expression of the porcine thyrotropin-releasing hormone receptor gene. Animal Biotechnology, 2011, 22 (1): 30-36.

Kato Y, Ezashi T, Hirai T, Kato T. The gene for the common alpha subunit of porcine pituitary glycoprotein hormone. J Mol Endocrinol 1991; 7: 27-34.

Kendall SK, Samuelson LC, Saunders TL, Wood RI, Camper SA. Targeted disruption of the pituitary glycoprotein hormone alpha-subunit produces hypogonadal and hypothyroid mice. Genes Dev 1995; 9: 2007-19.

Knott SA, Nystrom PE, Andersson-Eklund L, Stern S, Marklund L, Andersson L, et al. Approaches to interval mapping of QTL in a multigeneration pedigree: the example of porcine chromosome 4. Animal Genetics 2002; 33: 26-32.

Kokubo Y, Tomoike H, Tanaka C, Banno M, Okuda T, Inamoto N, et al. Association of sixtyone non-synonymous polymorphisms in forty-one hypertension candidate genes with blood pressure variation and hypertension. Hypertens Res 2006; 29: 611-9.

Li MD, Matteri RL, Macdonald GJ, Wise TH, Ford JJ. Overexpression of beta-subunit of thyroid-stimulating hormone in Meishan swine identified by differential display. J Anim Sci 1996; 74: 2104-11.

Liu XG, Tan LJ, Lei SF, Liu YJ, Shen H, Wang L, et al. Genome-wide association and replication studies identified TRHR as an important gene for lean body mass. Am J Hum Genet 2009; 84: 418-23.

Malek M, Dekkers JC, Lee HK, Baas TJ, Rothschild MF. A molecular genome scan analysis to identify chromosomal regions influencing economic traits in the pig. I. Growth and body composition. Mamm Genome 2001; 12: 630-6.

McDermott MT, Haugen BR, Black JN, Wood WM, Gordon DF, Ridgway EC. Congenital isolated central hypothyroidism caused by a "Hot Spot" mutation in the thyrotropin- $\beta$ gene. Thyroid 2002; 12:1141-1146.

Mekuchi M, Saito Y, Aoki Y, Masuda T, ligo M, Yanagisawa T. Molecular cloning, gene structure, molecular evolution and expression analyses of thyrotropin-releasing hormone receptors from medaka (Oryzias latipes). Gen Comp Endocrinol 2010.

Murani E, Muraniova M, Ponsuksili S, Schellander K, Wimmers K. Molecular characterization and evidencing of the porcine CRH gene as a functional-positional candidate for growth and body composition. Biochem Biophys Res Commun 2006; 342: 394-405.

Nagamine Y, Haley CS, Sewalem A, Visscher PM. Quantitative trait loci variation for growth and obesity between and within lines of pigs (Sus scrofa). Genetics 2003; 164: 629-635. 
Pfleger KD, Kroeger KM, Eidne KA. Receptors for hypothalamic releasing hormones TRH and GnRH: oligomerization and interactions with intracellular proteins. Semin Cell Dev Biol 2004; 15: 269-80.

Porterfield SP, White BA. Endocrine Physiology 3rd. Philadelphia, PA: Mosby Inc., 2007.

Sato S, Hasebe H, Sato S, Asahi Y, Hayashi T, Kobayashi E, et al. High-resolution physical mapping and construction of a porcine contig spanning the intramuscular fat content QTL. Anim Genet 2006; 37: 113-20.

Sun Y, Lu X, Gershengorn MC. Thyrotropin-releasing hormone receptors -- similarities and differences. J Mol Endocrinol 2003; 30: 87-97.

Takata M, Shimada Y, Ikeda A, Sekikawa K. Molecular cloning of bovine ThyrotropinReleasing Hormone Receptor gene. Journal of Veterinary Medical Science 1998; 60: 123-127.

van Wijk HJ, Buschbell H, Dibbits B, Liefers SC, Harlizius B, Heuven HC, et al. Variance component analysis of quantitative trait loci for pork carcass composition and meat quality on SSC4 and SSC11. J Anim Sci 2007; 85: 22-30.

Walling GA, Visscher PM, Andersson L, Rothschild MF, Wang L, Moser G, et al. Combined analyses of data from quantitative trait loci mapping studies. Chromosome 4 effects on porcine growth and fatness. Genetics 2000; 155: 1369-78.

Wallis M. Molecular evolution of the thyrotrophin-releasing hormone precursor in vertebrates: insights from comparative genomics. J Neuroendocrinol 2010; 22: 608-19.

Wimmers K, Murani E, Ponsuksili S, Yerle M, Schellander K. Detection of quantitative trait loci for carcass traits in the pig by using AFLP. Mamm Genome 2002; 13: 206-10.

Yerle M, Pinton P, Robic A, Alfonso A, Palvadeau Y, Delcros C, et al. Construction of a whole-genome radiation hybrid panel for high-resolution gene mapping in pigs. Cytogenet Cell Genet 1998; 82: 182-8. 


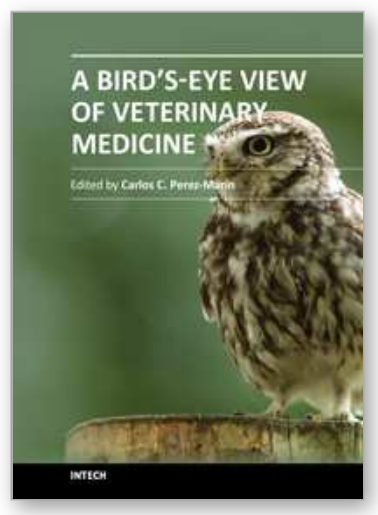

\author{
A Bird's-Eye View of Veterinary Medicine \\ Edited by Dr. Carlos C. Perez-Marin
}

ISBN 978-953-51-0031-7

Hard cover, 626 pages

Publisher InTech

Published online 22, February, 2012

Published in print edition February, 2012

Veterinary medicine is advancing at a very rapid pace, particularly given the breadth of the discipline. This book examines new developments covering a wide range of issues from health and welfare in livestock, pets, and wild animals to public health supervision and biomedical research. As well as containing reviews offering fresh insight into specific issues, this book includes a selection of scientific articles which help to chart the advance of this science. The book is divided into several sections. The opening chapters cover the veterinary profession and veterinary science in general, while later chapters look at specific aspects of applied veterinary medicine in pets and in livestock. Finally, research papers are grouped by specialisms with a view to exploring progress in areas such as organ transplantation, therapeutic use of natural substances, and the use of new diagnostic techniques for disease control. This book was produced during World Veterinary Year 2011, which marked the 250th anniversary of the veterinary profession. It provides a fittingly concise and enjoyable overview of the whole science of veterinary medicine.

\title{
How to reference
}

In order to correctly reference this scholarly work, feel free to copy and paste the following:

Ningying Xu and Xiaoling Jiang (2012). Molecular Characterization of Hypothalamo- Pituitary-Thyroid Genes in Pig (Sus Scrofa), A Bird's-Eye View of Veterinary Medicine, Dr. Carlos C. Perez-Marin (Ed.), ISBN: 978-95351-0031-7, InTech, Available from: http://www.intechopen.com/books/a-bird-s-eye-view-of-veterinarymedicine/molecular-characterization-of-thyroid-peroxidase-gene-in-porcine-sus-scrofa-

\section{INTECH}

open science | open minds

\section{InTech Europe}

University Campus STeP Ri

Slavka Krautzeka 83/A

51000 Rijeka, Croatia

Phone: +385 (51) 770447

Fax: +385 (51) 686166

www.intechopen.com

\section{InTech China}

Unit 405, Office Block, Hotel Equatorial Shanghai

No.65, Yan An Road (West), Shanghai, 200040, China

中国上海市延安西路 65 号上海国际贵都大饭店办公楼 405 单元

Phone: +86-21-62489820

Fax: $+86-21-62489821$ 
(C) 2012 The Author(s). Licensee IntechOpen. This is an open access article distributed under the terms of the Creative Commons Attribution 3.0 License, which permits unrestricted use, distribution, and reproduction in any medium, provided the original work is properly cited. 